\title{
Ultrastructural Properties and Immunolocalization of Relaxin in the Cytoplasmic Electron-Dense Granules of Large Luteal Cells During Pregnancy in the Cow
}

\author{
Tetsuya KOHSAKA ${ }^{1)}$, Hiroshi SASADA ${ }^{2)}$, Eimei SATO $^{2)}$, Kimio BAMBA ${ }^{1)}$ and \\ Kazuyoshi HASHIZUME ${ }^{3)}$
}

1) Laboratory of Animal Reproduction, Faculty of Agriculture, Shizuoka University, Shizuoka 422-8529, 2) Laboratory of Animal Reproduction, Graduate School of Agricultural Science, Tohoku University, Sendai 981-8555, and ${ }^{3)}$ Laboratory of Reproductive Endocrinology, National Institute Animal Industry, Ibaraki 305-0901, Japan

\begin{abstract}
In cattle, there is no direct evidence for subcellular localization of relaxin. This study investigated the ultrastructural features of the cytoplasmic electron-dense granules of bovine corpora lutea from the 4th month of gestation to near term, and the immunolocalization of relaxin in these granules. Corpora lutea collected from 28 Holstein cows were fixed with Bouin's solution for light microscopy or with $4 \%$ paraformaldehyde containing $0.3 \%$ glutaraldehyde followed by $1 \%$ osmium tetroxide for electron microscopy. Immunocytochemical detection of relaxin was done using polyclonal rabbit antiserum raised against purified porcine relaxin, and was performed by the peroxidase anti-peroxidase method or the protein A-gold technique for light and electron microscopy, respectively. Light microscopic immunocytochemistry showed immunostaining for relaxin in large luteal cells but not in small luteal cells. In the 4th month of pregnancy, weakly positive immunostaining of a few large cells was noted. Subsequently, the number of relaxin-positive cells and the intensity of immunostaining both increased gradually from the 7th month of pregnancy to near term. Ultrastructural examination revealed that the large luteal cells contained two types of cytoplasmic electron-dense granules, one being small granules of $100-300 \mathrm{~nm}$ in diameter and the other being large granules of 500-1800 nm. The small granules were abundant by the 7th month of pregnancy, decreased in number by the 9th month, and were absent near term. These granules were observed in the process of being released by exocytosis from the cell surface of the large luteal cells, especially in 4th to 6th months of pregnancy. In contrast, large granules were rare in the 4th month and then increased gradually to reach a maximum near term, and no evidence of their release from the luteal cells was obtained. After incubation with relaxin antiserum and protein A-gold, gold particles indicating relaxin immunoreactivity labelled the dense cores of most of the large granules but did not label small granules. These results indicate that the large luteal cells are the source of relaxin in the bovine corpus luteum during pregnancy and that electron-dense large granules are the subcellular site of relaxin storage within these cells.
\end{abstract}

Key words: Relaxin, Corpus luteum, Ultrastructure, Immunocytochemistry, Bovine

(J. Reprod. Dev. 47: 217-225, 2001)

$\mathbf{T}$ he mammalian corpus luteum (CL) is known to be the site of production of progesterone which

Accepted for publication: June 5,2001

Correspondence: T. Kohsaka is essential for the maintenance of pregnancy, and certain peptide hormones may also be produced by this tissue. Among these hormones, relaxin was first characterized in the pig [1-3] and the rat [4, 5], 
and has been reported to be localized in the electron-dense granules of luteal cells [6-11]. In cattle, it also appears that third trimester CL contains bioactive relaxin and the large luteal cells of the CL stain positively for porcine relaxin antiserum by the immunoperoxidase method [12], although the subcellular storage site of this hormone remains unclear.

In pregnant cows, the large luteal cells of the CL contain two types of electron-dense granules, i.e., small granules that are $100-300 \mathrm{~nm}$ in diameter and large ones that are 500-2000 $\mathrm{nm}$ in diameter [1316]. However, the exact nature of both types of granules has not been clarified. Fields et al. [16] reported that the small granules are first observed on day 45 of pregnancy and subsequently increase in number to reach a peak at around 200 days, suggesting that these small granules may be associated with peptide hormone synthesis, since they are packed in the Golgi apparatus, migrate as a group to the cell membrane, and are released by exocytosis. In contrast, it has been suggested that the large granules are derived from the mitochondria and that they may be a morphological feature related to changes in steroid synthesis $[13,14]$ or steroid metabolism [16].

We have established a fixation procedure that permits the very precise localization of relaxin together with the preservation of the ultrastructural details of a particular specimen [10]. The objective of the present study was to examine the ultrastructural features of the cytoplasmic electrondense granules in the bovine CL during pregnancy, and to clarify the subcellular localization of relaxin in these granules by applying our immunocytochemical method.

\section{Materials and Methods}

\section{Animals and tissue preparation}

CLs were collected at a local slaughterhouse from a total of 28 Holstein cows in the 4 th $(n=3), 5$ th $(n=$ $2), 6$ th $(n=6), 7$ th $(n=6), 8$ th $(n=4)$, and 9th $(n=5)$ months of pregnancy as well as from cows near term $(n=2)$. The duration of pregnancy was determined by measuring the fetal crown-rump length [17]. Each CL was divided into halves, and one half was cut into 5 - $\mathrm{mm}$ slices for light microscopy, while the other was cut into $1-\mathrm{mm}$ cubes for electron microscopy.
For light microscopy, the tissue slices were first fixed for $12 \mathrm{~h}$ at $4 \mathrm{C}$ by immersion in Bouin's solution. They were then embedded in paraffin, cut into $5-\mu \mathrm{m}$ sections, and mounted on gelatin-coated glass slides.

For electron microscopy, fixation of the specimens was performed as described previously [10]. In brief, tissue blocks were fixed for $2 \mathrm{~h}$ at $4 \mathrm{C}$ by immersion in $4 \%$ paraformaldehyde containing $0.3 \%$ glutaraldehyde in $0.01 \mathrm{M}$ phosphate-buffered saline (PBS, pH 7.2). Following overnight washing in PBS, the tissue blocks were postfixed for $1 \mathrm{~h}$ at 4 $\mathrm{C}$ in $1 \%$ osmium tetroxide in PBS, dehydrated in a graded acetone series, and embedded in epoxy resin. Then ultrathin sections were cut and placed on 150-mesh uncoated copper and nickel grids.

\section{Ultrastructural evaluation}

The sections on the copper grids were stained with uranyl acetate and lead citrate, and examined with a JEM-100B transmission electron microscope (JEOL, Tokyo, Japan) at $80 \mathrm{kv}$. Quantitative evaluation of the membrane-bound cytoplasmic granules was performed as follows. Randomly selected electron micrographs taken at a magnification of $\times 2,000$ were enlarged to $\times 6,000$, and the numbers of granules per cell was counted manually in 19-20 cells from a single animal in each month of pregnancy studied. The results obtained for each month of pregnancy were statistically analyzed using Student's $t$-test, and $p<0.01$ was considered to indicate a significant difference.

\section{Light microscopic immunocytochemistry}

The light microscopic immunocytochemical detection of relaxin was performed by the peroxidase-antiperoxidase procedure reported previously [11]. In brief, deparaffinized sections were treated for 20 min with $3 \%$ hydrogen peroxidase dissolved in pure ethanol to block endogenous peroxidase activity, and then incubated for 20 min with $2 \%$ normal goat serum to saturate nonspecific binding. The sections were next incubated with anti-porcine serum (diluted to 1: 500) for $12 \mathrm{~h}$ at $4 \mathrm{C}$, followed by incubation with goat anti-rabbit IgG (Cappel, West Chester, PA, U.S.A.) (1: 80) for $1 \mathrm{~h}$ at room temperature, and incubation with peroxidase-antiperoxidase (Cappel, West Chester, PA, U.S.A.) (1: 60) for $1 \mathrm{~h}$ at room temperature. After each step, the sections were washed three times for $5 \mathrm{~min}$ each in PBS. 
Visualization of peroxidase activity was performed using 3-3' diaminobenzidine (Sigma, St. Louis, MO, U.S.A.) as the substrate. After washing in running water, the sections were dehydrated in a graded ethanol series, mounted, and examined under an Olympus photomicroscope.

\section{Electron microscopic immunocytochemistry}

The electron microscopic immunocytochemical detection of relaxin was performed by the previously reported protein A-gold method [10]. In brief, ultrathin sections on nickel grids were preincubated in a saturated aqueous solution of sodium metaperiodate for $1 \mathrm{~h}$ at room temperature. Then the sections were incubated with porcine relaxin antiserum (1:500) for $12 \mathrm{~h}$ at $4 \mathrm{C}$, followed by washing in PBS containing $0.1 \%$ bovine serum albumin (BSA-PBS). Sections were next incubated with protein A-gold (Chemi-science, Tokyo, Japan)(1:30) for $30 \mathrm{~min}$ at room temperature, followed by washing in BSA-PBS and distilled water. All incubations were carried out in drops placed on parafilm in a moist chamber. After drying in air, the sections were stained with uranyl acetate, and then examined with a JEM-100B transmission electron microscope (JEOL, Tokyo, Japan) at $80 \mathrm{kV}$.

\section{Porcine relaxin antiserum}

The anti-relaxin serum used was the R19 antiserum raised in rabbits by Larkin et al. [18] against purified relaxin prepared from the ovaries of pregnant sows. This antiserum has been shown to inhibit the biological action of porcine relaxin in vitro [19] and to cross-react with partial purified bovine relaxin [12].

\section{Control}

The specificity of the immunoreactions was confirmed by using normal rabbit serum or antirelaxin serum absorbed with an excess of purified porcine relaxin standard (NIH-RXN-P1). To preabsorb the antiserum, $100 \mu \mathrm{g}$ of porcine relaxin [3] was added to $0.5 \mathrm{ml}$ of antiserum (diluted 1:500) and incubated for $5 \mathrm{~h}$ at $4 \mathrm{C}$.

\section{Results}

Cellular source of relaxin in the bovine $C L$

Throughout pregnancy, the bovine CL contained two types of luteal cells, i.e., large and small luteal cells. When CLs obtained in the 4th month of pregnancy were incubated with anti-porcine relaxin (diluted 1:500) and stained by the PAP technique, weakly positive immunostaining of a few large luteal cells was noted, but the small cells were unstained. The number of immunopositive cells and the intensity of the staining gradually increased from the 7th month of pregnancy to near term (Fig. 1a). No positive staining was observed when normal rabbit serum was used or when the anti-relaxin serum was preabsorbed with relaxin (Fig. 1b).

\section{Ultrastructure of the electron-dense granules in large luteal cells}

When the large luteal cells were examined by electron microscopy, they could be distinguished from the small cells by their size as well as by the possession of large mitochondria and numerous membrane-bound dense granules (Fig. 2). The rough endoplasmic reticulum (RER) was not well developed and was dispersed within the cytoplasm as short parallel stacks or isolated cisternae. Mitochondria were mostly round to oval-shaped, with only occasional elongated mitochondria being seen. The mitochondrial matrix showed occasional osmiophilic inclusions. The morphology and distribution of these organelles did not undergo any distinguishable changes during pregnancy.

A striking feature of the large luteal cells was the presence of dense granules surrounded by a limiting membrane. These dense granules included both small granules of 100 to $300 \mathrm{~nm}$ in diameter (Fig. 3a) and large granules of 500 to $1,800 \mathrm{~nm}$ (Fig. $3 b)$. The changes in the number of these granules per large luteal cell during the course of pregnancy are shown in Table 1.

By the 6th month of pregnancy, numerous small granules were distributed in clusters throughout the cytoplasm of the large luteal cells (Figs. 4 and 5), and were also often found near the periphery (Fig. 6). Occasionally, small granules were observed in the process of being released into the extracellular space by exocytosis (Fig. 7). A slight decrease in the number of small granules was noted in the 7 th month (Fig. 8), but there was no significant difference between the 6th and 7th months (Table 1). However, small granules showed a progressive decrease in number during the last trimester and had decreased significantly by the 9th month (Fig. 

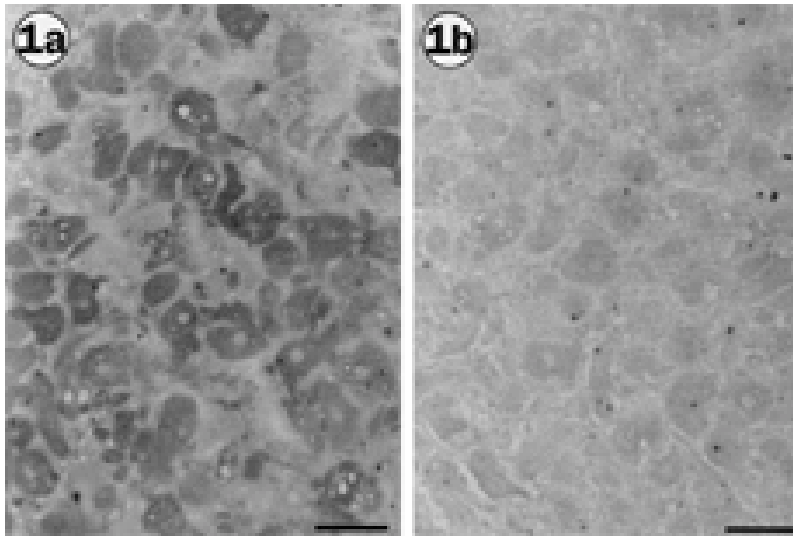

Fig. 1. Corpus luteum in the 9th month of pregnancy. a: Staining by the peroxidase anti-peroxidase (PAP) technique with anti-porcine relaxin (1:500 dilution). Reaction products indicating relaxin immunoreactivity can be noted in the majority of the large luteal cells. bar $=50 \mu \mathrm{m}$. b: Staining by the PAP technique with preabsorbed antiserum $(0.5 \mathrm{ml}$ of anti-porcine relaxin diluted 1:500 and preabsorbed with $100 \mu \mathrm{g}$ of the porcine relaxin standard). Immunostaining of the large luteal cells is almost completely abolished. Bar $=50 \mu \mathrm{m}$.

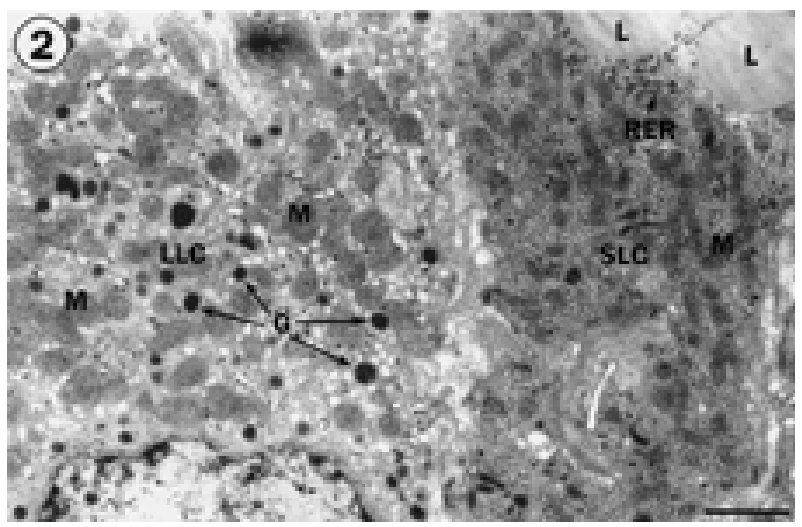

Fig. 2. Large and small luteal cells in the 7th month of pregnancy. The large luteal cell (LLC) is characterized by numerous oval-shaped mitochondria (M) and a large number of cytoplasmic electron-dense granules (G). The small luteal cell (SLC) is distinguished from the large cell by the presence of well-developed rough endoplasmic reticulum (RER) with parallel cisternal stacks, as well as numerous lipid droplets (L) and rod-shaped smaller mitochondria (M). Bar=1 $\mu \mathrm{m}$.

9, Table 1). Almost no small granules could be found near term (Fig. 10).

Unlike the small granules, large granules did not show any cytoplasmic polarity. No large granules

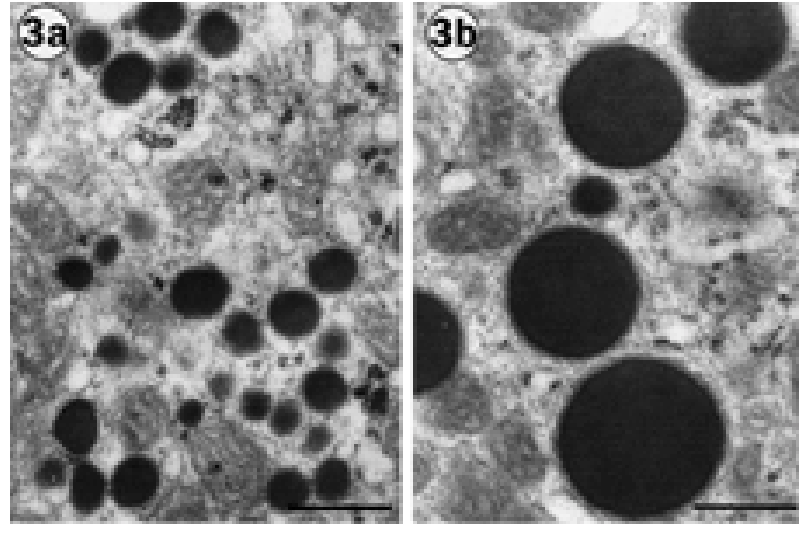

Fig. 3. Cytoplasmic electron-dense granules in large luteal cells. Two types of granules, i.e., large and small granules, are shown in these micrographs. a: High magnification of small granules ranging from 100$300 \mathrm{~nm}$ in diameter. Bar $=1 \mu \mathrm{m}$. b: High magnification of large granules ranging from 500-1,800 $\mathrm{nm}$ in diameter. Bar $=1 \mu \mathrm{m}$.

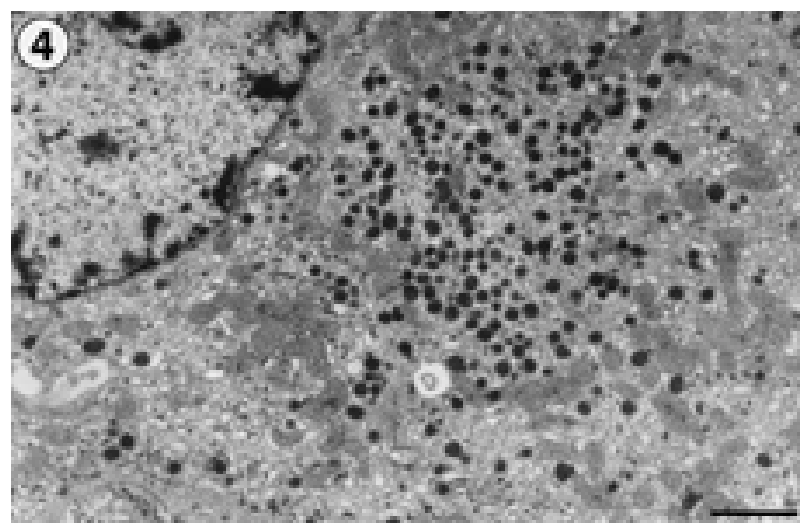

Fig. 4. A large luteal cell in the 4th month of pregnancy. Numerous small granules are distributed in clusters throughout the cytoplasm. A few large granules are also scattered within this cell. Bar $=2 \mu \mathrm{m}$.

were seen at the periphery of the cells or in the extracellular space adjacent to the plasma membrane. In the 4 th month of pregnancy, a few large granules were scattered throughout the cytoplasm (Fig. 4) and their number had not changed by the 6 th month (Figs. 5 and 6). However, a progressive increase in the number of granules was observed in the 7th month (Fig. 8). Granules numbers remained stable again in the 8 th and 9th months (Fig. 9) and then another increase occurred near term (Fig. 10), although there was no significant change (Table 1). 



Fig. 5. A large luteal cell in the 5th month of pregnancy. Small granules form clusters throughout the cytoplasm, displaying a similar distribution to those in the cell shown in Fig. 4. Large granules are scattered in the cytoplasm and their number remains unchanged compared to the 4th month. Bar $=2 \mu \mathrm{m}$.

Fig. 6. A large luteal cell in the 6th month of pregnancy. Note the numerous small granules in clusters near the periphery of the cell. Bar $=2 \mu \mathrm{m}$.

Subcellular localization of relaxin in the electrondense granules of large luteal cells

To examine the subcellular localization of relaxin in the large luteal cells, ultrathin sections were incubated with polyclonal rabbit antiserum directed against purified porcine relaxin and with protein A-gold. Gold particles indicating immunoreactivity for relaxin labeled the dense cores of most of the large granules (Fig. 11a), but there was no labeling of the small granules (Fig. $11 b)$. In addition, there was no gold labeling of other subcellular organelles, such as the mitochondria, RER, SER, lipid droplets, and nuclei. The immunolabeling in the large granules was sufficiently blocked by incubation with either normal rabbit serum or porcine relaxin antiserum preabsorbed with purified porcine relaxin (Fig.
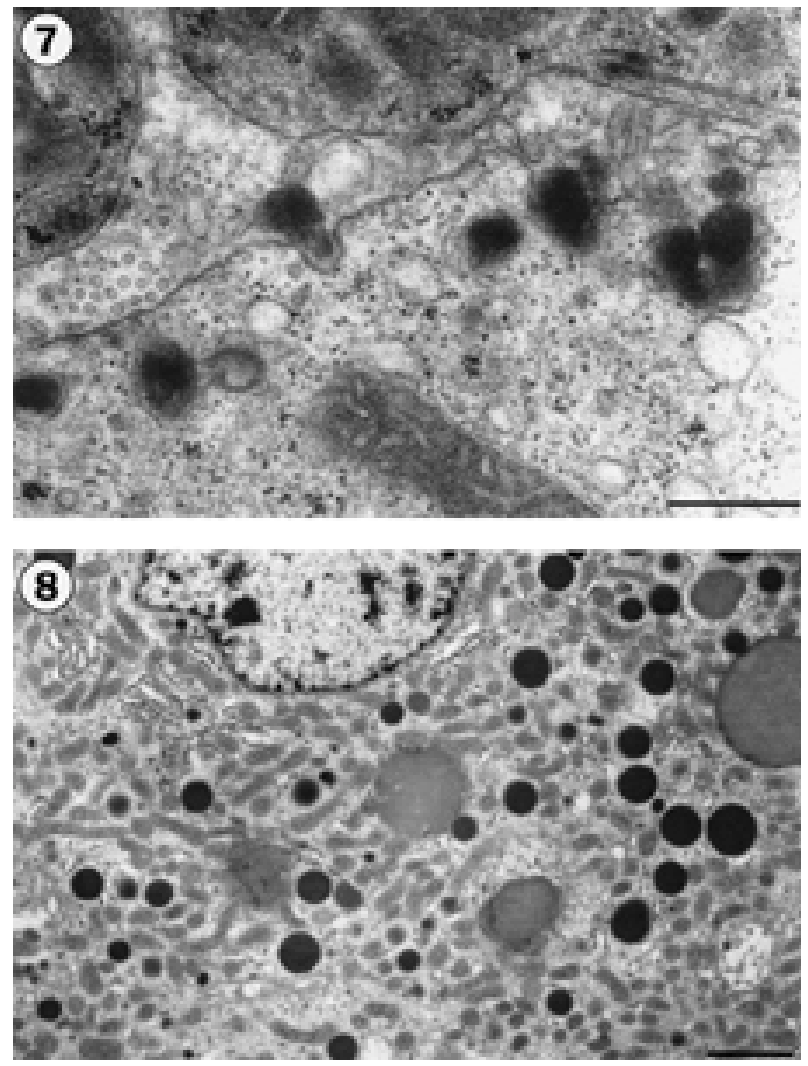

Fig. 7. A large luteal cell in the 6th month of pregnancy. Note small granules in the process of being released into the extracellular space by exocytosis. Bar $=500$ nm.

Fig 8. A large luteal cell in the 7th month of pregnancy. Small granules have decreased slightly in number, whereas the large granules show a progressive increase. Bar $=2 \mu \mathrm{m}$.

11c), indicating that the labeling was specific.

\section{Discussion}

Although relaxin has previously been detected in the large luteal cells of the pregnant bovine CL [12], its subcellular localization was not established. The present study clearly indicated that large luteal cells in the CL were the cellular source of relaxin and that the electron-dense large granules represented the subcellular site of relaxin localization within these cells. These findings both confirm and extend the work of Fields et al. [12].

As shown in the present and previous studies [13-16], the large luteal cells of pregnant cows contain at least two types of electron-dense 

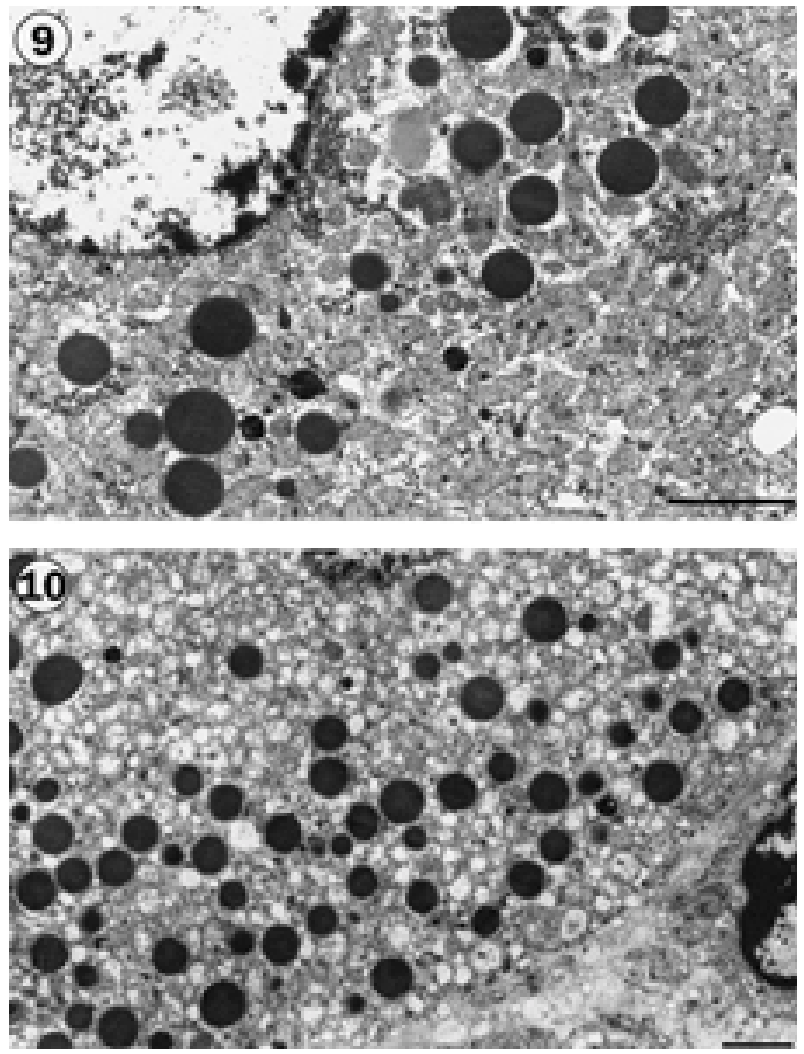

Fig 9. A large luteal cell in the 9th month of pregnancy. Numerous large granules are observed in the cytoplasm, but the small granules are no longer visible. Bar $=2 \mu \mathrm{m}$.

Fig. 10. A large luteal cell near term. Note that the cytoplasm is filled with large granules, but there is no evidence of secretion. Bar $=2 \mu \mathrm{m}$.

granules (small granules 100-300 $\mathrm{nm}$ in diameter and large granules 500-2,000 $\mathrm{nm}$ in diameter), although the nature of these granules remains uncertain. Fields et al. [16] reported that the small granules are first observed on day 45 of pregnancy and increase in number to reach a peak around day 200. They also suggested that the small granules may be associated with peptide hormone synthesis, since they are packed in the Golgi apparatus, migrate as a group to the cell membrane, and are released by exocytosis. Singh [14] reported that these small granules increase in number around days 230 to 245 of pregnancy, in an examination of luteal cells between days 60 and 245 of pregnancy. In the present study, we also found similar changes of the small granules, which were abundant by the 7 th month of pregnancy, decreased in number by
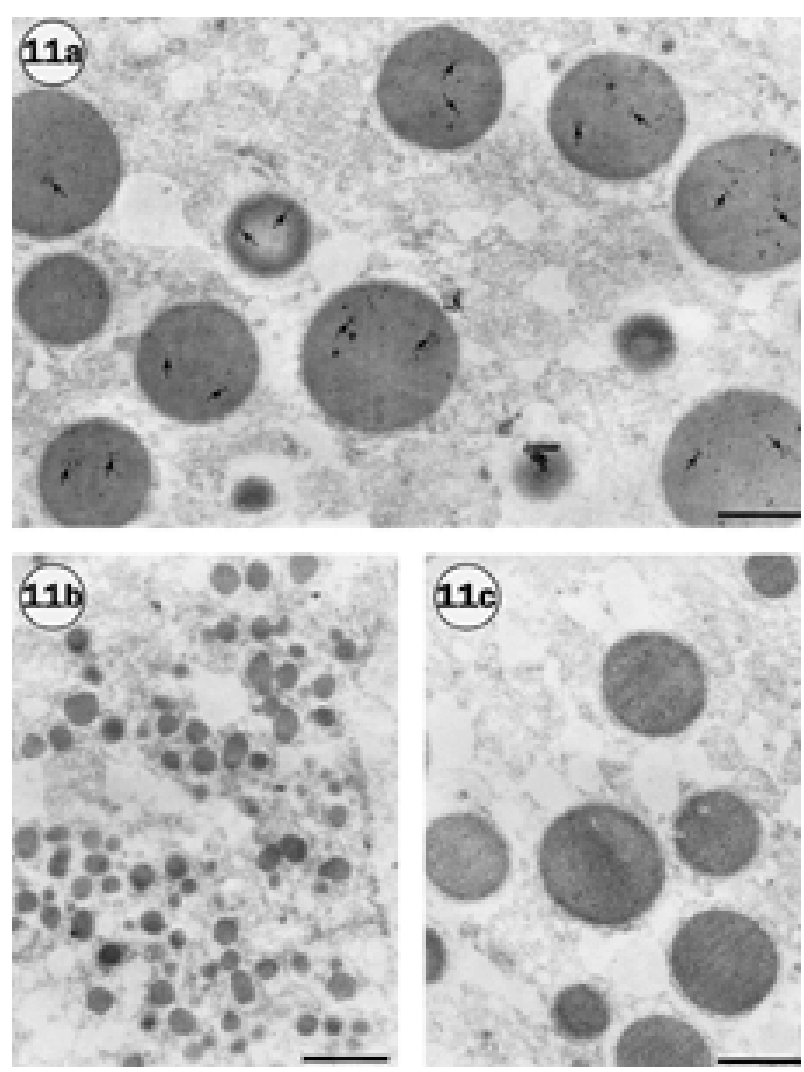

Fig. 11. Ultrastructural localization of relaxin in the large luteal cells. a: A large luteal cell in the 9th month of pregnancy labeled with anti-porcine relaxin (1:500 dilution) followed by protein A-gold. Note that the gold particles indicating relaxin immunoreactivity are mainly labeling the dense cores of the large granules (arrows). Bar $=1 \mu \mathrm{m}$. b: A large luteal cell in the 6th month of pregnancy labeled with anti-porcine relaxin (1:500 dilution) followed by protein A-gold. Note that no immunolabeling of the small granules can be seen. Bar $=1 \mu \mathrm{m}$. c: A large luteal cell in the 9th month of pregnancy labeled with preabsorbed antiserum $(0.5 \mathrm{ml}$ of anti-porcine relaxin diluted 1:500 and preabsorbed with $100 \mu \mathrm{g}$ of the porcine relaxin standard) followed by protein A-gold. Note that gold labeling of the large granules has been almost blocked. Bar=1 $\mu \mathrm{m}$.

the 9th month, and were absent near term.

In contrast to the small granules, the present study showed that large granules were sparse in the 4 th month of pregnancy, and increased in number from the 7 th month to reach a peak near term. In addition, there was no evidence of the secretion of large granules. Previous investigators have reported that granular structures like the large granules are found in the mitochondria $[13,14,16]$, 
Table 1. Changes in the mean $( \pm$ S.E.M) number of granules per large bovine luteal cell during pregnancy

\begin{tabular}{|c|c|c|c|}
\hline \multirow{2}{*}{$\begin{array}{l}\text { Month of } \\
\text { pregnancy }\end{array}$} & \multirow{2}{*}{$\begin{array}{c}\text { No. of cells* } \\
\text { examined }\end{array}$} & \multicolumn{2}{|c|}{ No. of granules/cell } \\
\hline & & Small granules & Large granules \\
\hline 4th & 20 & $114.2 \pm 21.6^{\mathrm{a}}$ & $8.3 \pm 1.8^{\mathrm{a}}$ \\
\hline 6th & 20 & $94.9 \pm 19.4^{\mathrm{a}}$ & $17.5 \pm 5.5^{\mathrm{ab}}$ \\
\hline 7 th & 19 & $83.6 \pm 21.9^{\mathrm{a}}$ & $37.9 \pm 8.5^{\mathrm{bc}}$ \\
\hline 9th & 20 & $35.6 \pm 9.7^{b}$ & $40.8 \pm 7.1^{\mathrm{c}}$ \\
\hline Near term & 20 & $4.2 \pm 1.0^{\mathrm{c}}$ & $54.6 \pm 10.9^{c}$ \\
\hline
\end{tabular}

${ }^{*}$ Cells were examined at a magnification of $\times 2,000$. Values with different superscripts in the same column are significantly different $(\mathrm{p}<0.01)$.

and that they begin to accumulate in the mitochondria as gestation progresses [14], or during the last months of pregnancy [16], to such an extent as to occlude the cristae. Although we also observed electron-dense inclusions in the matrix of a few mitochondria, we were not able to find any conclusive evidence that they developed into large granules. These mitochondria-like large granules have been postulated as occurring as a result of the condensation of certain metabolic products in close relation to steroid synthesis [13, 14] or to a change in steroid metabolism [16]. If these speculations were correct, no labeling of the large granules would have been observed. However, the present study clearly showed that the large granules were immunoreactive for relaxin, but not the small granules. In fact, we were completely unable to detect any relaxin in the small granules. The ability of our immunoelectron microscopic technique to detect relaxin has been discussed in detail elsewhere, and it permits the very precise localization of relaxin molecules along with the preservation of ultrastructural details [10]. Furthermore, we found that the changes in the number of large granules closely paralleled the changes in relaxin immunostaining of the bovine CL during pregnancy. Therefore, it seems reasonable to conclude that the large granules are not steroid-related, but instead are relaxincontaining granules, although their origin and pathway of secretion were not established in this study.

Using a heterologous radioimmunoassay for porcine relaxin, it has been shown that the concentration of immunoreactive relaxin in the peripheral blood of heifers is low during late pregnancy, increases significantly to a peak level at parturition, and then decreases abruptly during early lactation $[20,21]$. This is consistent with the behavior of the large granules, which show a marked increase in numbers near term prior to parturition, again suggesting that the large granules in the large luteal cells of the bovine CL are relaxin-containing granules.

The relaxin-containing granules in the cow appeared to be similar in density to the relaxincontaining granules of the luteal cells in pregnant rats $[7,8,10]$ and pigs $[6,9,11]$. However, they are considerably larger than the granules found in both these other species, which have a diameter of 100$300 \mathrm{~nm}$. The significance of this species difference in granule size is unclear, but it is not too surprising since large granules containing relaxin are also known to exist in the endometrial gland cells of the guinea pigs [22].

Small granules similar to those described in our study have also been observed previously in the large luteal cells of cyclic cows [23] and sheep [24$26]$. These granules were postulated to contain progesterone [24-26] and/or progesterone-binding proteins [23]. However, recent investigators [2729] could find no supporting evidence for these hypotheses. Recent immunocytochemical and in vitro cell culture studies have indicated that oxytocin and neurophysin are restricted to the large luteal cells of cyclic cows [30] and sheep [31-33]. Furthermore, ultrastructural immunocytochemical studies have established the presence of oxytocin and/or neurophysin in the small granules of the large luteal cells in cyclic sheep [34]. The nature of the contents of the small granules found in the large luteal cells of pregnant cows is still unclear. However, relaxin is definitely not present in these small granules, because there was no evidence of immunolabeling in the present study. It is possible that the changes of these small granules during 
pregnancy may reflect some critical endocrine event which has not yet been identified, as suggested by Fields et al. [16]. In any event, the small granules in the large luteal cells of pregnant cows appear to be secretory granules that do not contain relaxin, and their exact role needs to be established in future studies.

In conclusion, this study indicates that the large luteal cells are the source of relaxin in the bovine corpus luteum during pregnancy and that electrondense large granules are the subcellular site of relaxin storage within these cells.

\section{Acknowledgments}

The authors thank Dr. L. H. Larkin, Department of Anatomy, University of Florida College of Medicine, for the kindly supplying porcine relaxin antiserum R19; and National Hormone and Pituitary Program, National Institutes of Health in US, for kindly providing the purified porcine relaxin (HIH-RXN-P1). This work was supported in part by Grants-in-Aid to T.K. from the Ministry of Education, Science and Culture of Japan.

\section{References}

1. Sherwood OD, O'Byrne EM. Purification and characterization of porcine relaxin. Arch Biochem Biophys 1974; 160: 185-196.

2. Bullesbach EE, Schwabe C. Naturally occurring porcine relaxin and large-scale preparation of the B29 hormone. Biochem 1985; 24: 7717-7722.

3. Kohsaka T, Takahara H, Sugawara K, Tagami S. Endogenous heterogeneity of relaxin and sequence of the major form in pregnant sow ovaries. Biol Chem 1993; 374: 203-210.

4. Sherwood OD. Purification and characterization of rat relaxin. Endocrinology 1979; 104: 886-892.

5. Walsh JR, Niall H. Use of an octadecylsilica purification method minimizes proteolysis during isolation of rat relaxin. Endocrinology 1980; 107: 1258-1260.

6. Kendall JZ, Plopper CG, Bryant-Greenwood GD. Ultrastructural immunoperoxidase demonstration of relaxin in corpora lutea from a pregnant sow. Biol Reprod 1978; 18: 94-98.

7. Anderson MB, Sherwood OD. Ultrastructural localization of relaxin immunoreactivity in corpora lutea of pregnant rats. Endocrinology 1984; 114: 11241127.

8. Fields PA. Intracellular localization of relaxin in membrane-bound granules in the pregnant rat luteal cell. Biol Reprod 1984; 30: 753-762.

9. Fields PA, Fields MJ. Ultrastructural localization of relaxin in the corpus luteum of the nonpregnant, pseudopregnant, and pregnant pig. Biol Reprod 1985; 32: 1169-1179.

10. Kohsaka T, Sasada H, Masaki J. Subcellular localization of the antigenic sites of relaxin in the luteal cells of the pregnant rat using an improved immunocytochemical technique. Anim Reprod Sci 1992a; 29: 123-132.

11. Kohsaka T, Takahara H, Sasada H, Kawarasaki T, Bamba K, Masaki J, Tagami S. Evidence for immunoreactive relaxin in boar seminal vesicles using combined light and electron microscope immunocytochemistry. J Reprod Fert 1992b; 95; 397408.

12. Fields MJ, Fields, PA, Castro-Hernandez A, Larkin LH. Evidence for relaxin in corpora lutea of late pregnant cow. Endocrinology 1980; 107: 869-876.

13. Sorensen VW, Singh UB. On mitochondrial inclusions in granulosa lutein cells of pregnant cows. Experientia 1973; 29: 592-593.

14. Singh UB. Structural changes in the granulosa lutein cells of pregnant cows between 60 and 245 days. Acta Anat 1975; 93: 447-457.

15. Kohsaka T, Niimura S, Ishida $\mathbf{K}$. Ultrastructure of bovine corpus luteum graviditatis. Jap J Anim Reprod 1982; 28: 109-111.

16. Fields MJ, Dubois W, Fields PA. Dynamic features of luteal secretory granules: Ultrastructural changes during the course of pregnancy in the cow. Endocrinology 1985; 117: 1675-1682.

17. Evans HE, Sack WO. Prenatal development of domestic and laboratory mammals: Growth curves, external features and selected references. Anat Histol Embryol 1973; 2: 11-45.

18. Larkin LH, Fields PA, Oliver RM. Production of antisera against electrophoretically separated relaxin and immunofluorescent localization of relaxin in porcine corpus luteum. Endocrinology 1977; 101: 679-685.

19. Larkin LH, Suarez-Quian CA, Fields PA. In vitro analyses of antisera to relaxin. Acta Endocrinologica 1979; 92: 568-576.

20. Anderson LL, Perezgrovas R, O'Byrne EM, Steinets BG. Biological actions of relaxin in pigs and beef cattle. Ann New York Acad Sci 1982; 380: 131150.

21. Caldwell RW, Bellows RA, Hall JA, Anthony RV. Administration of pig relaxin to beef heifers 4 or 7 days prepartum. J Reprod Fert 1990; 90: 165-174.

22. Pardo RJ, Larkin LH, Renegar RH. Immunoelectron 
microscopic localization of relaxin in endometrial gland cells of the pregnant guinea pig. Anat Rec 1984; 209: 373-379.

23. Parry DM, Willcox DL, Thorburn GD. Ultrastructure and cytochemical study of the bovine corpus luteum. J Reprod Fert 1980; 60: 349-357.

24. Gemmell RT, Stacy BD, Thorburn GD. Ultrastructural study of secretory granules in the corpus luteum of the sheep during estrous cycle. Biol Reprod 1974; 11: 447-462.

25. Quirk SJ, Willcox DL, Parry DM, Thorburn GD. Subcellular localization of progesterone in the bovine corpus luteum: a biochemical, morphological and cytochemical investigation. Biol Reprod 1979; 20: 1133-1145.

26. Sawyer HR, Abel JH, McClellan MC, Schmitz M, Niswender GD. Secretory granules and progesterone secretion by ovine corpora lutea in vitro. Endocrinology 1979; 104: 476-486.

27. Sernia C, Thorburn GD, Gemmell RT. Search for a progesterone-binding protein in secretory granules of the ovine corpus luteum. Endocrinology 1982; 110: 2151-2158.

28. Hirst JJ, Rice GE, Jenkin G, Thorburn GD. Secretion of oxytocin and progesterone by ovine corpora lutea in vitro. Biol Reprod 1986; 35: 11061114.

29. Rice GE, Jenkin G, Thorburn GD. Comparison of particle-associated progesterone and oxytocin in the ovine corpus luteum. J Endocrinol 1986; 108: 109-116.

30. Guldenaar SEF, Wathes DC, Pickering BT. Immunocytochemical evidence for the presence of oxytocin and neurophysin in the large cells of the bovine corpus luteum. Cell Tissue Res 1984; 237: 349352.

31. Rodgers RJ, O'Shea JD, Findlay JK, Flint APF, Sheldrick EL. Large luteal cells the source of luteal oxytocin in the sheep. Endocrinology 1983; 113: 23022304.

32. Watkins WB. Immunohistochemical localization of neurophysin and oxytocin in the sheep corpora lutea. Neuropeptides 1983; 4: 51-54.

33. Sawyer HR, Moeller CL, Kozlowski GP. Immunocytochemical localization of neurophysin and oxytocin in ovine corpora lutea. Biol Reprod 1986; 34: 543-548.

34. Theodosis DT, Wooding FBP, Sheldrick EL, Flint APF. Ultrastructural localization of oxytocin and neurophysin in the ovine corpus luteum. Cell Tissue Res 1986; 243: 129-135. 